\title{
The structure of a shock wave close to a wall
}

\author{
F. SEILER, M. WORNER and B. SCHMIDT (KARLSRUHE)
}

THB FLOW field at the foot of a shock wave, travelling along a wall, is investigated. Results of density measurements are compared with numerical data which were calculated by means of the direct Monte Carlo simulation method. Close to the wall large gradients in the flow variables develop; the influence of the parameters, shock strength, the intermolecular force law and accommodation coefficient will be discussed. Finally, the first numerical results for a binary gas mixture of Ho-Ar show a different separation effect in the shock wave than in the shear layer close to the wall.

Zbadano pole przepływu u podstawy fali uderzeniowej posuwającej się wzdhù ścianki. Wyniki pomiarów gestości porównano z danymi liczbowymi otrzymanymi za pomocą bezpośredniej symulacji Monte Carlo. W poblizu scianki wystepują wysokie gradienty zmiennych przepływu; omawia się wpływ intensywnosci uderzenia, prawa rządzacego silami międzyczasteczkowymi i wspólczynnika akomodacji. Pierwsze wyniki liczbowe otrzymane dla dwuskładnikowej mieszaniny gazbw Ho-Ar wskazują na zjawisko oderwania w fali uderzeniowej odmienne od zjawiska zachodzacego $\mathrm{w}$ warstwie poslizgu przy sciance.

Исследовано поле течения в основе ударной волны, движущейся вдоль стенки. Резултаты измеренй плотности сравневы с числовыми дағшыми, полученшии при помощи непосредственной имитации Монте-Карло. Вблизи стенки выступают высокие градиенты переменшых течения; обсуждается влияние итенсивности удара, закона отисываюоего межмолекулярные сишы и козффициента приспособления. Первые шисловые резултты, полушенпые дия двухкомпонентной смеси газов Не-Аr, указиаюо̆т на явление отрыва в ударной волне, отличающееся от явления провсходящего в слое скольжения при степке.

\section{Introduction}

THB FLow field at the foot of a shock wave, travelling along a wall into a stagnant gas, is investigated. Figure 1 shows a sketch of the region of interest. Due to the contact of the gas with the wall, the gas particles set in motion by the shock wave are slowed down and a two-dimensional flow field develops. The gradients of the flow variables become large,

Fio. 1. Sketch of the region of interest.

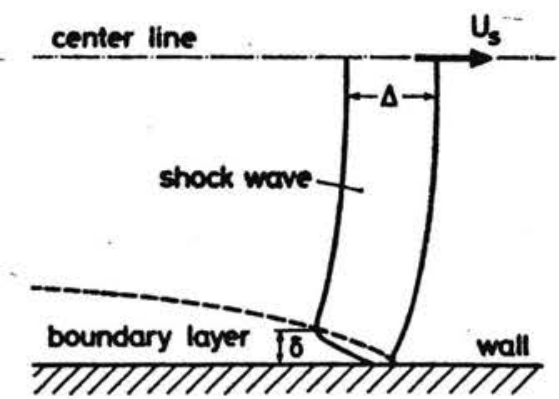


especially close to the wall. Here the gradients are much larger than in the undisturbed shock wave far from the wall. Characteristic lengths in the problem are the shock thickness $\Delta$ at the centerline and the thickness $\delta$ of the wall influenced region at the end of the shock wave (see Fig. 1).

\section{Numerical treatment of the problem}

The direct simulation Monte Carlo method, as developed by BIRD [1], has been used to obtain numerical data for comparison with the experimental results. Figure 2 shows the model used for the two-dimensional simulation. In a two-dimensional channel a piston

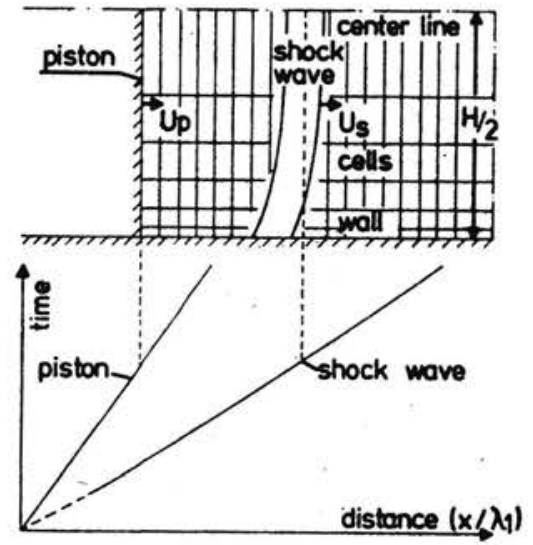

Fig. 2. Model for the two dimensional direct simulation Monte Carlo method.

is suddenly set in motion and moves into the stagnant gas. The gas in front of the piston is simulated by a limited number of model molecules ( 8000 to 15000 molecules). The simulated flow field, being bound by the piston, the centre or symmetry line, a right border far enough from the piston and the solid wall, is subdivided into a limited number of cells. The size of a cell is such that the change of the molecular quantities is small over a cell. For the solid wall a simple accommodation model has been chosen. At the three other field boundaries the molecules are reflected specularly. For the simulation a nondimensional model-time is advanced in discrete steps. The molecules move according to their individual velocities and collision pairs are chosen randomly in a cell according to their relative speed. For the collision process an intermolecular force law is chosen. The molecular movement and the collision process are decoupled. After a certain number of discrete time steps the two-dimensional flow pattern with a shock wave moving along the solid wall evolves. The macroscopic quantities (density, pressure, temperature, mean velocity) are extracted by sampling and averaging in each cell over the different moments of the cell distribution function. Since the model number density per cell is small, the macroscopic quantities fluctuate about an unknown mean value. The fluctuations can be reduced by taking more molecules per cell or by repeating the simulation process several times and averaging the macroscopic quantities. Limits of these procedures are set by the demand in computer storage capacity and in computing time. 
To get information about the influence of the side walls on the flow, a three-dimensional simulation of the real flow field in the test chamber is set up. Here the possibilities are much more limited than in the two-dimensional case because the demand in storage capacity and computing time soon become excessive.

The only theoretical treatment of the problem known to the authors is a continuum approach by SiCHEL [2]. Sichel used modified Navier-Stokes equations to get an analytical solution for the two-dimensional problem without piston and extending to infinity perpendicular to the wall. Due to the fact that the main influence of the wall is limited to a region very close to the wall, a comparison of Sichel's results with numerical results should allow one to draw some conclusions. The continuum approach limits Sichel's results to weak shock waves $\left(M_{s} \lesssim 1.3\right)$.

\section{Experiment}

A simple low density shock tube of a $150 \mathrm{~mm}$ inner diameter was used to generate the shock waves. At the end of the driven section a 90 by $90 \mathrm{~mm}$ test section was attached and a square cookie cutter in front of the test section cut out a square piece of the shock wave. For the measurements close to a wall a flat plate with a sharp leading edge was inserted into the test section with the flat upper surface parallel to the top wall and with $H=77 \mathrm{~mm}$ below it (Fig. 4). The shock wave adapts very fast to the new surfaces as can be deduced from the experimental results. A fully-developed flow can be expected at the location of the density measurements.

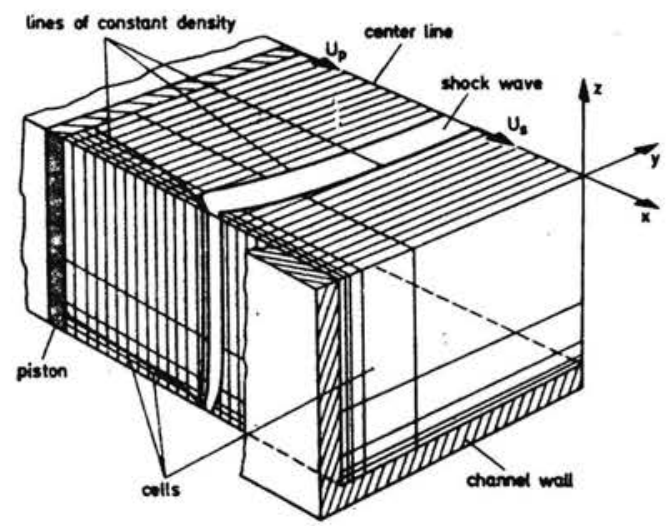

FIG. 3. Model for the three dimensional direct simulation Monte Carlo method.

The local gas density has been estimated from the measured local density gradients of a multibeam laser differential interferometer. Four interferometers with a beam spacing of $3.3 \mathrm{~mm}$ were arranged perpendicular to the flat plate (see Fig. 4). The effective beam diameter in the test section was $0.19 \mathrm{~mm}$. This arrangement, shown in Fig. 5 for one of these interferometers, provided a sufficient resolution in time and space if $p_{1}$ ahead of the shock wave was below $\approx 13.33 \mathrm{~N} / \mathrm{m}^{2}$ ( 0.1 Torr). 


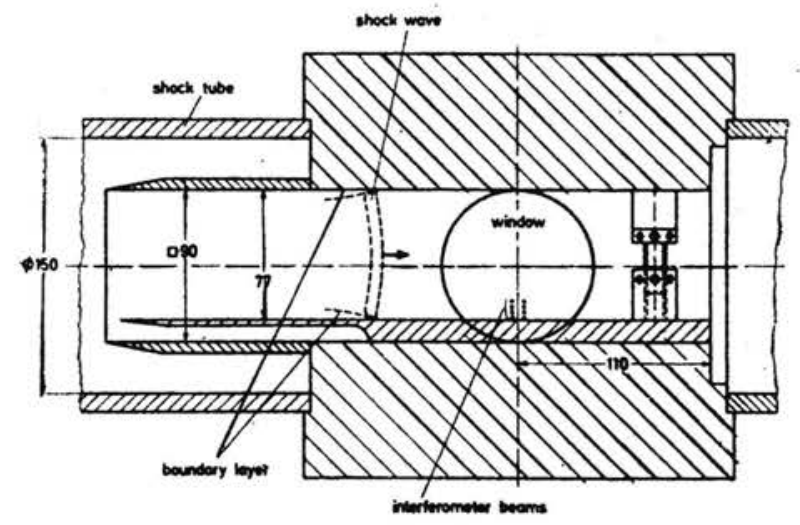

FiG. 4. Test section close to the end of the driven section of the shock tube.

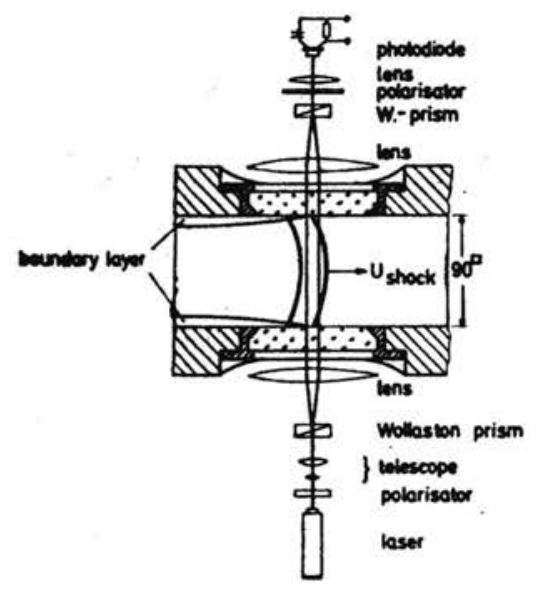

Fio. 5. Arrangement for one of the four Laser Differential Interferometers of Fig. 4.

\section{Results}

As Fig. 6 shows, the density profiles calculated with the use of Sichel's continuum approach and those of the Monte Carlo simulation are similar. The agreement may improve if the continuum approach is not extended to its limits $\left(M_{s} \approx 1.3\right)$ and a more appropriate intermolecular force law is used for the simulation. Further, the simulation gives averages for the density over the cell height $\Delta y$ whereas the continuum approach gives the density profile at exact $y=$ const.

In Figs. 7 to 10 experimental results for shock Mach numbers between 2.13 and $\mathbf{9 . 2 1}$ are compared with numerically calculated ones. The most interesting density profile is the one closest to the wall $y / \lambda_{1}=0.28$. For the numerical results a pure repulsive intermolecular force law, $F \sim r^{-p}, \nu=10$ and full accommodation at the wall $(\alpha=1.0)$ is used. On the other hand the calculated density profiles for $y / \lambda_{1}=0.28$ grow steadily to higher density values with increasing shock strength and for the same distance behind the shock measured ones reach a maximum at about $M_{a} \approx 4$ and drop slightly for stronger 


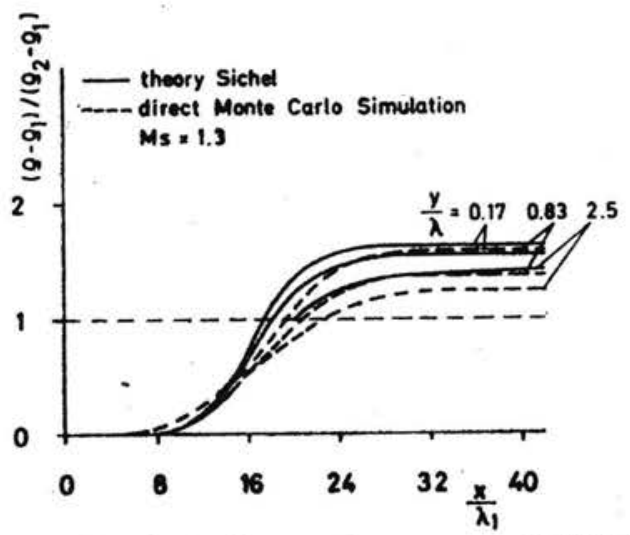

Fic. 6. Comparison of results gained with a continuum approach (Sichel) and with the simulation method.

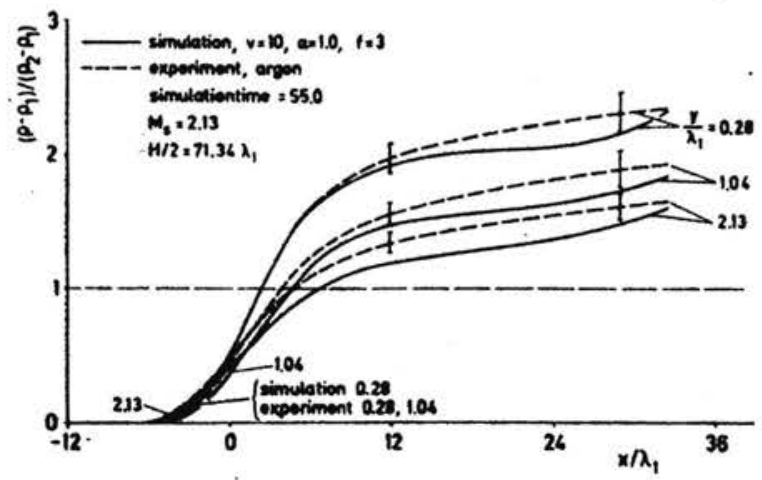

FIG. 7. Comparison of experimental results with results of the simulation Monte Carlo method.

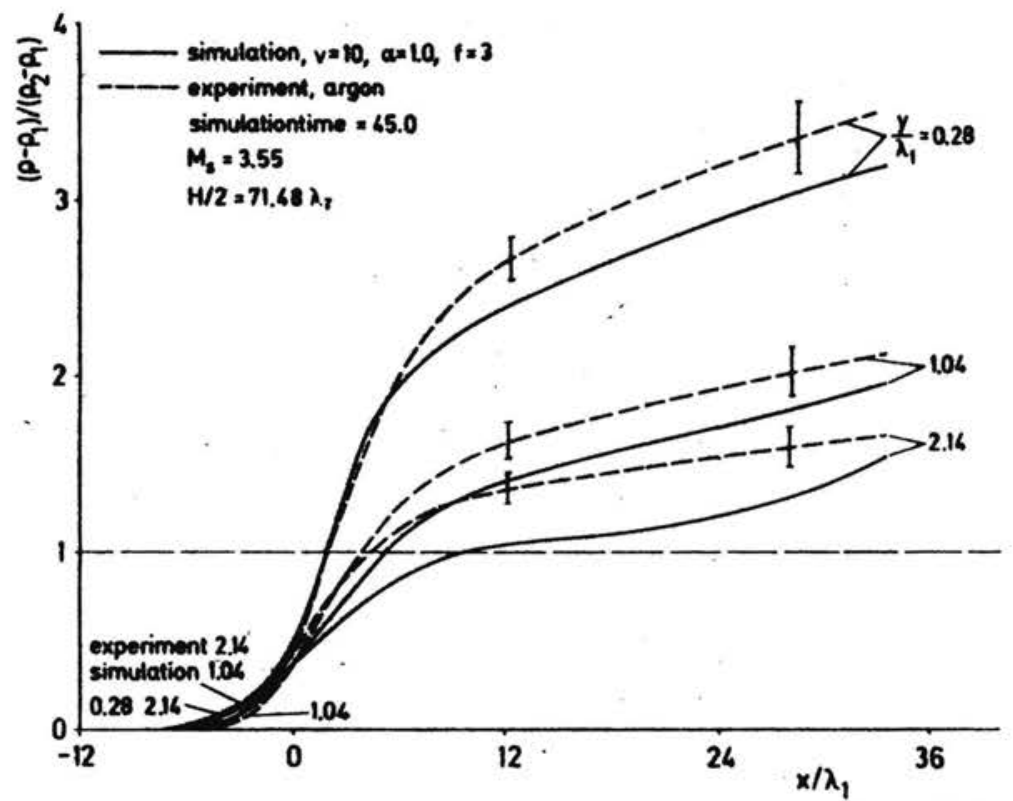

Fig. 8. Comparison of experimental results with results of the simulation Monte Carlo method. 
shock waves. Further, for weak shock waves the experimental density profiles, especially for $y / \lambda_{1}=0.28$, are above the calculated ones whereas for strong shocks the experimental profiles are below the calculated ones. This result indicates changes in the accommodation

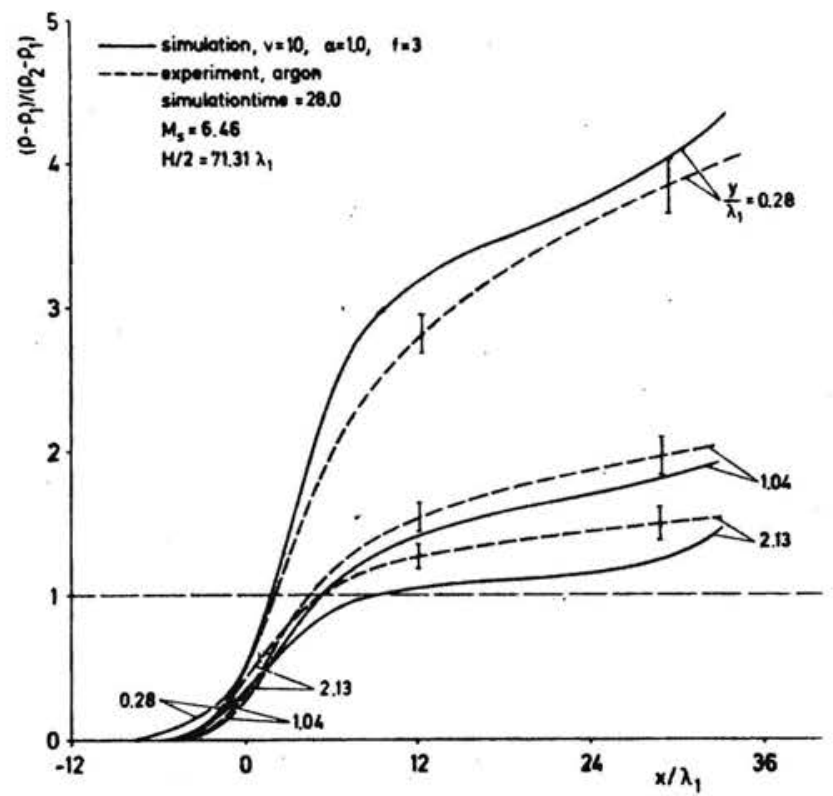

Fig. 9. Comparison of experimental results with results of the simulation Monte Carlo method.

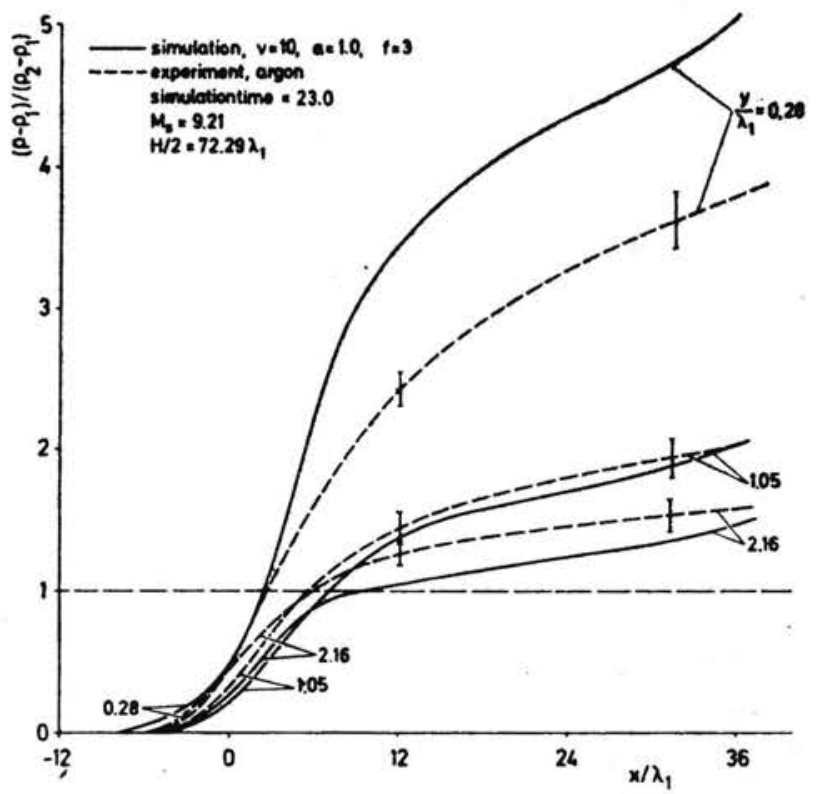

Fig. 10. Comparison of experimental results with results of the simulation Monte Carlo method. 
at the wall with increasing shock strength. Full accommodation $(\alpha=1.0)$ seems to be appropriate for weak shocks only.

Comparing the overall pattern of the measured and the calculated density profiles, especially the ones closest to the wall, the pure repulsive intermolecular force law $\left(F \sim r^{-v}\right.$, $v=10$ ) gives better results than the rigid sphere model for strong shock waves (see Figs. 8 and 11). For weak shock waves $M_{s} \lesssim 2.5$ ) this repulsive force law becomes too

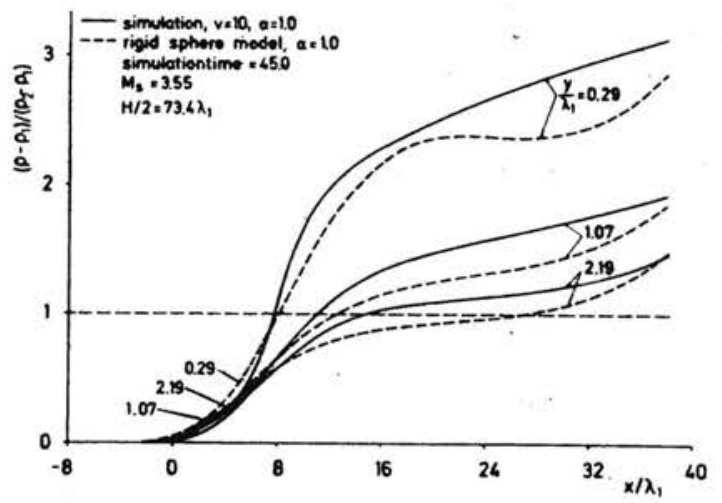

Fic. 11. The influence of the intermolecular force law becomes visible. For this shock strength the pure repulsive force law follows the experimental results better (compare Fig. 8).

hard and a weaker repulsive force law with $v<10$ should be used or a force law with an attractive and a repulsive part (Lennard-Jones potential).

The influence of the wall decreases very fast with the distance from the wall. Two or three mean free path distances from the wall the density profiles do not go much above

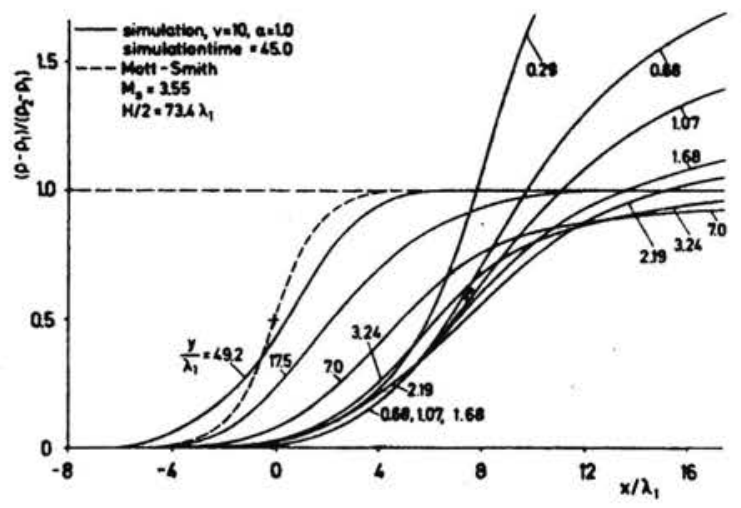

Fio. 12. An influence of the wall is visible up to the center of the channel. Compare Mott-Smith profile and profile for the center closest boxes $y / \lambda_{1}=49.2$.

the value $\left(\varrho-\varrho_{1}\right) /\left(\varrho_{2}-\varrho_{1}\right)=1$ (see Fig. 12). Nevertheless the influence of the wall is visible up to the center of the channel. The profile closest to the centerline (Fig. 12, $y / \lambda_{1}=$ $=49.2$ ) deviates markedly from the Mott-Smith profile for an undisturbed normal shock. 
For the shock strength used here $\left(M_{2}=3.55\right)$, the Mott-Smitt profile is known to be almost identical to experimental results [3].

A three-dimensional simulation (see Fig. 3) is started to obtain information about the distortion of the interferometer signal due to the influence of the shear layers at the windows, especially at the corners close to the flat plate. The simulation results obtained up to now indicate, as expected, a density rise from the center towards the windows (for $z=$ constant) with a maximum in the corner. Averaging over a cell layer with $z=$ constant in the three-dimensional simulation is similar to the integration of the density distribution along the path of the interferometor beams. A comparison of the averaged three-dimensional simulation with the results of a two-dimensional simulation, performed for the samo shock strength $M_{0}$ and wall distance $y / \lambda_{1}$, should allow an estimation of the difference

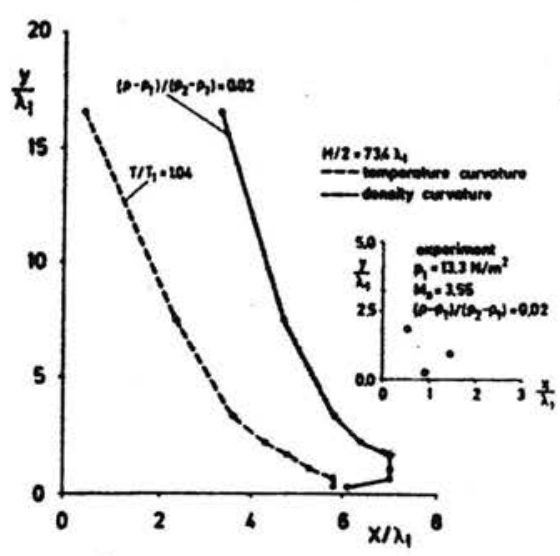

Fio. 13. Shock front curvature profiles for constant density, constant temperature and measured (density) arrivial times.

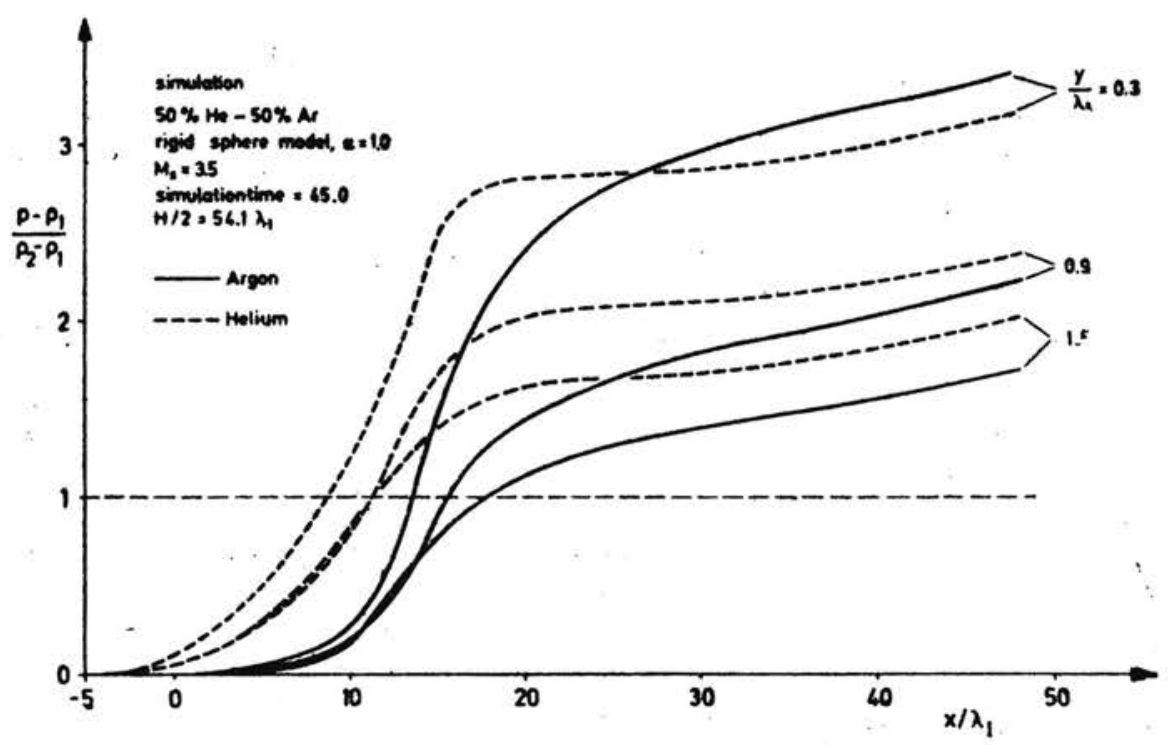

Fic. 14. Change in the separation of a binary gas mixture in the region close to the wall. 
between the two-dimensional simulation and the experimental results. Qualitatively comparable experimental density profiles should fall above two-dimensional calculated ones.

Figure 13 shows constant density and constant temperature shock front profiles for $M_{s}=3.55$, calculated with the simulation method. The density profile develops a foreward facing foot close to the wall. This foot becomes more pronounced with increasing shock strength. The temperature shock front does not develop such a foot. As indicated by the insert in Fig. 14, the density measurements show this foot, too. The temperature could not be measured, but shock front arrival measurements, done with thin film gauges [4], do not show such a foot. Thin film gauges respond to the gas temperature and density and the temperature effect seems to override the density effect. A gaskinetic explanation for the foot may be that fast molecules coming from the rear part of the shock wave penetrate the slower ones at the front and are retarded by contact with the wall. This results in an accumulation of molecules in front of the shock wave close to the wall.

\section{Binary gas mixture}

Figure 14 shows the results for a simulation calculation for a binary gas mixture of $50 \%$ heavy gas (argon) and 50\% light gas (helium). The mass ratio is 10:1. The separation of the two components in the shock wave and in the shear layer at the wall is clearly visible. In the shock wave the light gas compresses first whereas in the shear layer and close to the wall the heavy component compresses more. At more than one mean free path distance from the wall the compression of the heavy component is always behind the compression of the light component. Figure 15 shows the calculated constant density

FIG. 15. Density shock front curvatures for a binary mixture of $50 \%$ heavy to $50 \%$ light gas ( $\mathrm{Ar}-\mathrm{He}$ ).

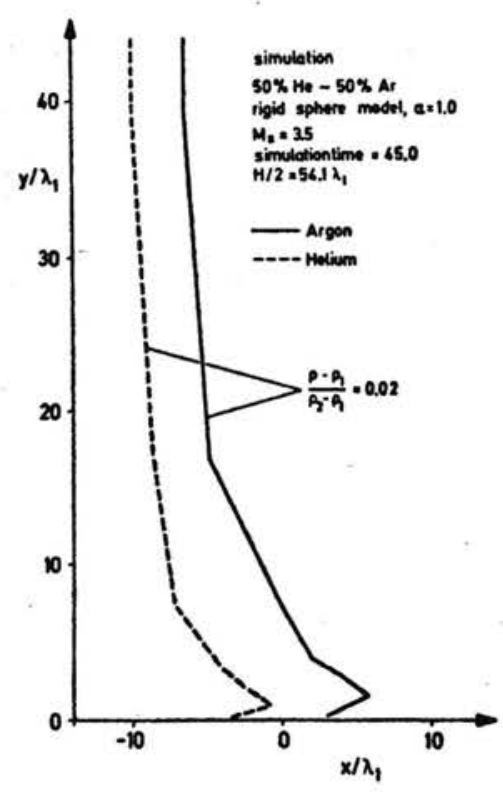

shock front profiles for the two components. The separation is obvious and changes with the distance from the wall. The forward facing foot is developed by both components.

Experiments on gas mixtures are in preparation. It is planned to do density measurements by using the electron beam luminiscence method. 


\section{Conclusions}

The large gradients observed in a shock wave close to a wall make this region particularly interesting for the investigation of effects connected with large deviations from local thermal equilibrium. Close to the wall the gradients are much larger than in an undisturbed normal shock wave.

The comparison of calculated and experimental results allows the separation of the influence of the intermolecular force law and the accommodation at the wall. Full accommodation does not hold for strong shock waves and the pure repulsive intermolecular force law $r^{-p}$ with $v=10$ does not give density profiles similar to the measured profiles for all shock strengths $\left(2.13 \lesssim M_{s} \lesssim 9.25\right)$. The density profile closest to the wall is the most sensitive one to these parameters. The calculated density profiles for a binary gas mixture of $50 \% \mathrm{He}-50 \%$ Ar show some unexpected results. In the shock wave the heavy component lags the light one in compression whereas very close to the wall the density of the heavy component rises above that of the light one. This is not observed outside one to two mean free path distances from the wall.

The large amount of numerical work has been done on the UNIVAC 1108 and the Burroughs B 7700 of the university computing center at Karlsruhe and the IBM 370/168 of the university computing center at Heidelberg. The support of this work by the Deutsche Forschungsgemeinschaft is appreciated.

\section{References}

1. G. A. Bird, Molecular gas dynamics, Oxford University Press, London 1976.

2. M. Sichea, Leading edge of a shock induced boundary layer, Phys. Fluids, 5, 1168-1180, 1962.

3. A. ALSMEYER, Density profiles in argon and nitrogen shock waves measured by the absorption of an electron beam, J.F.M, 74, 3, 497, 1976.

4. B. SçMmit, The shock wave curvature close to the shock tube wall, Arch. Mech., 28, 5/6, 809-815, 1976.

INSTITUT FUR STROMUNGSLBHRE UND STRÖMUNGSMASCHINEN UNTVERSITXT KARLSRUHE, FRG.

Received October 25, 1979. 